\title{
Wyzwania konserwatywnej polityki rządu Lee Myung-baka na przykładzie antyamerykańskich protestów przeciwko importowi wołowiny do Korei
}

\author{
Challenges of Lee Myung-bak's Administration Conservative \\ Policy on the Anti-American Beef Protests Case
}

\begin{abstract}
Streszczenie:
W 2008 r. konserwatywna administracja Lee Myung-baka musiała zmierzyć się z masowymi protestami. Demonstranci sprzeciwiali się nagłej oraz nieprzemyślanej ich zdaniem decyzji prezydenta dotyczącej zniesienia ograniczeń w imporcie amerykańskiej wołowiny. Masowy ruch społeczny w kraju doprowadził do nieoczekiwanych politycznych reperkusji. Celem artykułu jest ukazanie, jak przebiegały protesty oraz jak czynniki kulturowe, ekonomiczne i narodowe wpływają i determinują kierunki politycznego rozwoju.
\end{abstract}

Słowa kluczowe: rząd Lee Myung-baka, antyamerykańskie protesty, wołowina, Korea

\begin{abstract}
:
In 2008, the Lee Myung-bak's conservative administration encountered mass protests among South Korean citizens that opposed to decision to abolish the import ban on American beef. These anti-American social protests and its trajectories were determined not only by cultural but economic factors. The purpose of this study is to acquaint with the U.S. Beef Protests in the Korean Peninsula and familiarize the conservative politics of the Lee Myung-bak's regime. This case shows how cultural, national and economic factors emphasize and determine different political reverberations.
\end{abstract}


Dominik Wróblewski - Wyzwania konserwatywnej polityki...

Keywords: the Lee Myung-bak's conservative administration, U.S. Beef Protests, beef, Korea

\section{Wprowadzenie}

$\mathrm{Z}$ racji ustanowionego po II wojnie światowej sztucznego podziału na dwa wrogie sobie państwa koreańskie zastosowane $\mathrm{w}$ artykule terminy Korea i Koreańczycy oznaczają Koreę Południową i jej społeczeństwo.

Na przełomie maja i lipca 2008 r. tysiące demonstrantów wyszło na ulice największych miast Republiki Korei. Manifestanci przeciwstawiali się decyzji Lee Myung-baka dotyczącej zniesienia ograniczeń w imporcie amerykańskiej wołowiny, które nałożono w 2003 r. ze względu na wybuch epidemii choroby szalonych krów. Mieszkańców kraju zaktywizowały decyzje ówczesnego prezydenta chcącego znieść powyższe ograniczenia. Demonstracje przerodziły się w prawdziwy ruch narodowy ${ }^{1}$. Ich skutkiem było wystosowanie publicznych przeprosin przez Lee Myung-baka, wybranego prawie cztery miesiące wcześniej, który wspomnianą decyzją stracił poparcie społeczeństwa. Dodatkowo prezydent zapowiedział reorganizację swojego gabinetu.

Koreańczycy uznali kontrowersyjną decyzję prezydenta za zagrażającą zdrowiu człowieka. W dodatku działania protestujących zapoczątkowały i spotęgowały antyrządowe demonstracje ${ }^{2}$. W związku $\mathrm{z}$ tym nasuwa się zasadnicze pytanie, dlaczego poczucie zagrożenia spowodowane zniesieniem ograniczeń w imporcie amerykańskiej wołowiny, wyrażone masowymi protestami, spowodowało takie implikacje polityczne?

\footnotetext{
${ }^{1}$ Choe Sang-hun, An Anger in Korea over More Than Beef, „New York Times” z dn. 12.06.2008 r. , http://www.nytimes.com/2008/06/12/world/asia/12seoul.html?_r=0 [dostęp: 24-05-2016].

2 광우병 괴담 깨졌지만... 시위꾼들, 이슈 바꾸며 '反정부 집회' [The Mad Cow Disease Ghost Has Broken...Protesters and Anti-Government Rally], „Chosun Ilbo” z dn. 2.05.2008 r., http://news.chosun.com/site/data/html_dir/2013/05/02/201305020 0038.html?Dep0=twitter\&d=2013050200038 [dostęp 24.05.2016].
} 


\section{Problematyka handlu wołowiną na linii USA-Republika Korei}

Od lat 90. XX w., Korea była ważnym rynkiem zbytu dla amerykańskiego mięsa wołowego. W 2003 r. ponad połowa skonsumowanej wołowiny pochodziła ze Stanów Zjednoczonych. Jak podkreślają Remy Jurenas i Mark E. Manyin, Korea była trzecim co do wielkości importerem eksporterem tego produktu3. W grudniu, w tym samym roku, w Waszyngtonie po raz pierwszy wykryto przypadek gąbczastej encefalopatii bydła, popularnie zwanej chorobą szalonych krów4

$\mathrm{Na}$ podstawie powyższych informacji Republika Korei podjęła decyzję o wstrzymaniu importu amerykańskiej wołowiny. Rząd USA poczynił starania, aby w części przywrócić handel. Seul zgodził się na import miękkiego mięsa (całkowicie pozbawionego kości) od krów nie starszych niż 30 miesięcy. Kryteria zostały oparte na głębokim przekonaniu, że krowy w tak młodym wieku nie są podatne na tę chorobę5. W latach 2004-2007 USA eksportowały bardzo małe ilości wołowiny na Półwysep Koreański. Jednakże mimo nałożonych restrykcji Korea była czwartym co do wielkości odbiorcą amerykańskiego mięsa wołowego ${ }^{6}$.

Strona amerykańska wywierała naciski na rząd w Seulu, aby anulował nałożone obostrzenia. W rezultacie zaproponowano politykę „dwóch faz”, która oznaczała najpierw sprowadzenie mięsa od młodszych krów. Natomiast w drugim etapie USA miały dostarczyć wołowinę od bydła starszego niż 30 miesięcy?

W kwietniu 2008 r. oba państwa doszły do porozumienia, na mocy którego restrykcje zostały zniesione. Według umowy ustalono nowe

\footnotetext{
${ }^{3}$ R. Jurenas, M. E. Manyin, US-South Korea Beef Dispute: Issues and Status, Congressional Research Service Report for Congress RL34528, 2010, s. 1.

${ }^{4}$ S. A. Lister, G. S. Becker, Bovine Spongiform Encephalopathy (BSE, or Mad Cow Disease): Current and Proposed Safeguards, Congressional Research Service Report for Congress RL32199, 2007, s. 2.

${ }^{5}$ R. Jurenas, M. E. Manyin, US-South Korea Beef Dispute..., op. cit., s. 3-4.

6 Ibidem, s. 5.

7 Inside U.S. Trade, Korean Minister Sees Open Beef Market in Two Steps, Delay in FTA Approval, 2007, s. 5.
} 
Dominik Wróblewski - Wyzwania konserwatywnej polityki...

regulacje sanitarne, eliminujące części ciała zawierające elementy określonego ryzyka ${ }^{8}$.

\section{Konserwatywne rządy a ich społeczny nonkonformizm}

Podczas kampanii prezydenckiej Lee Myung-bak promował swoją prezydenturę jako całkowicie różniącą się od rządów liberalnych poprzedników. Spotkało się to z dużym poparciem społeczeństwa niezadowolonego z działalności poprzednich władz. W swoim programie prezydenckim, tzw. Planie $747^{9}$, zadeklarował rewitalizację gospodarki poprzez ukształtowanie jej politycznego rozwoju. Nadto stwierdził, że dział ten został odsunięty na boczny tor podczas zbyt powszechnego w poprzednich rządach politykierstwa. Ogłosił również uczynienie za czasów swojej prezydentury gospodarki Republiki Korei siódmą gospodarką świata. Przewidywał utrzymanie przez Koreę corocznego 7\% wzrostu PKB, ale także osiągnięcie poziomu PKB równoważnemu 40 tys. USD na 1 mieszkańca oraz zapowiedział wybudowanie Wielkiego Koreańskiego Szlaku Wodnego, ciągnącego się od Pusanu

\footnotetext{
8 R. Jurenas, M. E. Manyin, US-South Korea Beef Dispute..., op. cit., s. 5-6.

${ }^{9}$ Lee Myung-bak 10 maja 2007 r. oficjalnie zgłosił swoją kandydaturę w wyborach prezydenckich $\mathrm{z}$ ramienia Wielkiej Partii Narodowej. Jego program prezydencki, tzw. Plan 747, nawiązywał do cech charakterystycznych samolotu Boeing 747, Lee's Campaign Pledges Need Another Look, „Chosun Ilbo” z dn. 24.12. 2007,

http://english.chosun.com/site/data/html_dir/2007/12/24/2007122461020.html [dostęp 24.05.2016]; Jak zauważa John Feffer, Lee Myung-bak zaraz po wygraniu wyborów miał doskonałą szansę, aby odnieść kolejny sukces. Pierwszy osiągnął, będąc burmistrzem Seulu w latach 2002-2006, kiedy postawił na innowacyjność technologiczną i industrializację. Według Feffera był to odpowiedni moment, aby nastąpił dalszy rozwój. W przyszłości, dzięki zmianom, Korea poradziłaby sobie z problemami XXI w., tj. globalnym ociepleniem czy narastającym kryzysem energetycznym. Przekształcenie kraju w raj środowiskowy, w którym powszechnie byłyby wykorzystywane elektrownie atomowe, mogłoby sprawić, że Lee odniósłby ogromny sukces $\mathrm{w}$ sferze gospodarki, polityki i nowych technologii. Zdaniem cytowanego autora, tak jak buldożer toruje nową drogę, tak Lee ze swoim Planem 747 powinien przetrzeć szlak nowym kierunkom rozwoju; J. Feffer, [Elect] A Green Bulldozer?, „Korea Times” $\quad \mathrm{z} \quad \mathrm{dn}$. 08.01 .2008 http://www.koreatimes.co.kr/www/news/nation/2008/01/116_16889.html [dostęp: 24-05-2016].
} 
do Seulu. Po zwycięstwie zadeklarował dalszą współpracę partnerską ze Stanami Zjednoczonymi obejmującą sferę gospodarczą, polityczną i militarną. W związku z tym w 2008 r. odbył swoją pierwszą zagraniczną podróż właśnie do USA, w trakcie której opowiedział się za ściślejszym handlem z amerykańskim partnerem. Co więcej, Lee Myung-bak miał na uwadze neutralne nastawienie amerykańskiego Kongresu dotyczące podpisania Free Trade Agreement (FTA) pomiędzy Koreą a USA ${ }^{10}$. W następstwie tego obiecał byłemu prezydentowi USA George'owi W. Bushowi zniesienie przez Republikę Korei ograniczeń w handlu amerykańską wołowiną. Tym samym dążył do zapewnienia Trade and Investment Framework Agreement (TIFA) ${ }^{11}$ ze Stanami Zjednoczonymi.

W przeciwieństwie do poprzednich ekip rządzących Lee Myungbak i jego gabinet mogli liczyć na silne parlamentarne poparcie. Wielka Partia Narodowa, z której ramienia kandydował, posiadała przeważającą większość, ponieważ zdobyła 153 na 299 miejsc w Zgromadzeniu Narodowym ${ }^{12}$. W tej sytuacji konserwatywny rząd Lee Myungbaka posiadał niezwykle dużą możliwość politycznych manewrów, co potencjalnie ułatwiało zniesienie obostrzeń związanych z importem amerykańskiej wołowiny.

Kwestia reorientacji polityki zagranicznej podczas prezydentury Lee Myung-baka również stanowi istotny aspekt w analizowanej pro-

\footnotetext{
10 Free Trade Agreement (FTA), bilateralna umowa zawarta między Koreą a USA w czerwcu 2007 r. W 2010 r. podpisano kolejną umowę związaną z FTA. Porozumienie wdrożono do praktyki 15 marca 2012 r. Na mocy umowy oba kraje ustanowiły strefę wolnego handlu, zniesiono cła oraz inne opłaty na wszystkie bądź niektóre towary. Jednakże wymagane jest utrzymanie kontroli celnej na granicach obu państw $\mathrm{w}$ celu zbadania źródła pochodzenia towaru; South Korea's Ministry of Foreign Affairs, http://www.mofa.go.kr/ENG/policy/fta/status/overview/index.jsp?menu=m_20_80 _10\&tabmenu=t_1 [dostęp: 24-05-2016].

11 Trade and Investment Framework Agreement (TIFA), wstępna umowa bilateralna Korei i USA do FTA; Office of the US Trade Representative, https://ustr.gov/ trade-agreements/trade-investment-framework-agreements [dostęp: 24-05-2016].

12 Był to najwyższy wynik od 1987 r., kiedy Korea weszła na drogę demokratycznych przemian; Moon, Chung-in, South Korea in 2008: From Crisis to Crisis, „Asian Survey" 2009, nr 1, s. 120-121.
} 
Dominik Wróblewski - Wyzwania konserwatywnej polityki...

blematyce. Ówczesny prezydent, uważany za konserwatystę, pragnął poprawić i zacieśnić koreańskie stosunki dyplomatyczne ze Stanami Zjednoczonymi, które od czasów prezydentury Roh Moo-hyuna uległy znacznemu ochłodzeniu ${ }^{13}$. Punktem zwrotnym w znormalizowaniu wzajemnych relacji miało być zniesienie wspomnianych już ograniczeń.

Jak podkreśla Doug McAdam, ruchy społeczne na podstawie koncepcji struktury politycznych możliwości interpretują, jak kontekst polityczny umożliwia, a zarazem ogranicza kolektywne działanie ${ }^{14}$. Niemniej jednak wspomniana procedura nie tłumaczy, dlaczego masowe protesty przybrały $\mathrm{w}$ tym państwie formę antyrządowych manifestacji na tak ogromną skalę. Społeczne niezadowolenie zobligowało Lee Myung-baka do renegocjacji umowy handlowej ze Stanami Zjednoczonymi.

Na szczególną uwagę w omawianej kwestii zasługuje rewolucyjna wręcz rola Internetu. Młodzi ludzie wykorzystali internetowe fora publiczne do błyskawicznego rozprzestrzenienia potrzebnych informacji15. Za przykład może posłużyć manifestacja w Seulu z dnia 2 maja 2008 r., której założenia i okoliczności zostały wcześniej omówione

13 Za czasów prezydentury Roh Moo-hyuna polityka zagraniczna nastawiona była na dalszą ściślejszą współpracę oraz swoiste ocieplanie stosunków z Koreą Północną. Polityka zapoczątkowana za czasów prezydentury Kim Dae-junga nie spotkała się z przychylnymi reakcjami ze strony Stanów Zjednoczonych. Jednakże za Roh Moohyuna zintensyfikowano współpracę w sferze gospodarczej i społecznej - umożliwiono kolejne spotkania rozdzielonych rodzin koreańskich. Słoneczna Polityka skutkowała pogorszeniem stosunków dyplomatycznych na linii Seul-Waszyngton. Natomiast za rządów Lee Myung-baka relacje z Koreańską Republiką Ludowo-Demokratyczną uległy pogorszeniu. Nastąpił odwrót od Słonecznej Polityki. Nowy rząd skupił się na poprawie stosunków z USA. Podjęte w tym zakresie działania kontynuowała późniejsza prezydent Park Geun-hye; G. Strnad, Korea. Polityka południa wobec Północy w latach 1948-2008. Zmiana i kontynuacja, Instytut Zachodni, Poznań 2014, s. 339$504,515$.

${ }^{14}$ D. McAdam, Conceptual Origins, Current Problems, Future Directions [w:] D. McAdam, J. D. McCarthy, M. Y. Zald (red.), Comparative Perspectives on Social Movements. Political Opportunities, Mobilizing Structures and Cultural Framings, Cambridge Studies in Comparative Politics, Cambridge 1999, s. 23-30.

15 Kim Yang-cheol, Kim June-woo, South Korean Democracy in the Digital Age: The Candlelight Protests and the Internet, „Korea Observer” 2009, nr 1, s. 53-83. 
na Agorze ${ }^{16}$. Protestujący, używając telefonów komórkowych, połączyli się z serwisem Google Maps, ustalając dokładną trasę demonstracji. Wykorzystano także kamery internetowe do nadania transmisji na żywo z odbywającego się pochodu ${ }^{17}$. Działania protestujących wyeksponowały słabość rządu, który nieumiejętnie starał się zdyskredytować rolę Internetu, uznając go za źródło bezpodstawnych plotek ${ }^{18}$. W następstwie w kraju odbyły się liczne dysputy popularnonaukowe dowodzące istnienia technologicznej przepaści pomiędzy zinternetyzowanym społeczeństwem a rządem korzystającym z technologii analogowej $^{19}$.

Należy dokonać tu wyjaśnienia. Nie umniejszając doniosłej funkcji, jaką spełnił Internet, trzeba zauważyć, że uczestnicy protestów nie zmobilizowaliby się, używając tylko jednej konkretnej metody. W Republice Korei istnieją niezależne i rzetelne agencje informacyjne, które również zostały wykorzystane. Ponadto Korea należy do światowych potentatów szybkiego Internetu. Co oznacza, że aktywiści w swoich działaniach wykorzystali różne narzędzia przeciwko konserwatywnemu rządowi. Konkretyzując, młode pokolenie Koreańczyków na ponad dwa miesiące zintegrowało się przeciw agresywnej polityce rządu Lee Myung-baka, ale w swoich działaniach wykorzystało rozmaite źródła przekazywania informacji.

Aby zrozumieć koreańską politykę importową, należy rozpatrzyć aspekt strukturalny pod kątem aspektu kulturowego. David A. Snow

\footnotetext{
${ }^{16}$ Agora - popularne forum internetowe w Korei.

17 Trzeba wziąć pod uwagę, że Korea jest jednym z najbardziej zinternetyzowanych krajów na świecie. Żadne inne społeczeństwo nie zatraciło się w Internecie tak, jak koreański naród. 81\% obywateli korzysta z bardzo szybkiego Internetu, o średniej przepustowości 14.58 Mbps. Obecnie ponad 90\% gospodarstw domowych ma dostęp do sieci. Młodzi ludzie znacznie częściej spędzają czas, przeglądając fora internetowe, czy grając w popularne gry sieciowe; Internet w południowej Korei, „Blox” z dn. 07.02.2011, http://internetum.blox.pl/2011/02/Internet-w-poludniowej-Korei. html [dostęp: 24-05-2016].

18 Min Kyung-bae w swojej publikacji użył bardziej wyrazistego określenia, mianowicie: szamba bezpodstawnych plotek; Min Kyung-bae, Analog Government, Digital Citizens, „Global Asia” 2008, nr 3, s. 94-103.

19 Ibidem, s. 94-103.
} 
Dominik Wróblewski - Wyzwania konserwatywnej polityki...

i Robert D. Benford, zajmujący się tematyką ruchów społecznych, doszli do wniosku, że krzywdy ${ }^{20}$ doznane w przeszłości nie stanowią obiektywnego czynnika, powodującego rozpoczęcie protestów. Jednakże w trakcie protestów wykorzystywane są one do tworzenia konstruktywnych analiz i komunikatów, które można nazwać procesem umieszczania w „ramach”21. W tej perspektywie omawiane koreańskie manifestacje są zrozumiałe. Co więcej, ich przekaz słowny odnosi sukces. Innymi słowy, aktywiści musieli stworzyć silną więź pomiędzy protestującymi a sprawą, przeciwko której odbyły się demonstracje. Im silniejsza była więź, tym większa liczba ludzi wzięła udział w manifestacjach.

Opierając się na teorii „ram”, zauważyć można uzasadniony strach Koreańczyków wobec amerykańskiej wołowiny. Ważnymi kwestiami w Korei, które należy poruszyć w omawianym temacie, są nacjonalizm i nastawienie do ewentualnych zagrożeń. W ostatnim czasie zaobserwowano powolny wzrost nastrojów antyamerykańskich w tym państwie. Stany Zjednoczone nie jawią się już jako gwarant ochronny przed komunistycznym reżimem z Północy. Coraz częściej spotykane są nieprzychylne opinie na temat USA, które uważane są przez społeczeństwo za samolubne mocarstwo, pragnące za wszelką cenę utrzymać swoje bazy wojskowe na Półwyspie Koreańskim. Długa i wyboista droga do demokracji Korei powiązana była z indygenizacją kulturową oraz z rosnącym znaczeniem tożsamości narodowej22. Oznacza

\footnotetext{
20 Termin jest fałszywy. Używany ogólnie nie stanowi czynnika decydującego o mobilizacji społeczeństwa i nie uznaje się go za podstawę do wszczynania protestów; S. Rastegari Henneberry, Hwang Seong-huyk, Meat Demand in South Korea: An Application of the Restricted Source-Differentiated Almost Ideal Demand System Model, „Journal of Agricultural and Applied Economics” 2007, nr 1, s. 47.

${ }^{21}$ D. A. Snow, R. D. Benford, Ideology, Frame Resonance, and Participant Mobilization. [w:] B. Klandermans, H. Kriesi, S. Tarrow (red.), From Structure to Action: Comparing Social Movement Research across Cultures, London 1988, s. 197-218.

22 Należy poczynić tutaj szerszą uwagę. Globalizacja intensyfikuje homogenizację oraz etnocentryzm i nacjonalizm. Indygenizacja, która jest jednym z procesów globalizacji, pełni ważną funkcję wśród Koreańczyków. Następuje wzmacnianie oraz utrwalanie tożsamości i więzi lokalnych, co z kolei może przerodzić się w zdecydowane reakcje, np. omawiana fala antyrządowych protestów.
} 
to, że percepcja USA jako ziemi obiecanej odchodzi w zapomnienie. Następuje proces postrzegania tego kraju w kategoriach zagrożenia dla suwerenności i bezpieczeństwa narodowego Korei. Dlatego też zniesienie ograniczeń dotyczących importu wołowiny zostało odebrane przez Koreańczyków jako zdrada interesu narodowego.

Kolejne istotne zagadnienie $\mathrm{w}$ danej problematyce stanowi kulturowe podejście do kwestii jedzenia. Obywatele Korei spożywają najwięcej wołowiny ze wszystkich narodów azjatyckich. W państwie dostępna jest lokalna wołowina - hanwoo, jednakże jest to stosunkowo drogi produkt. W związku z tym import amerykańskiego mięsa stanowi ważne uzupełnienie diety Koreańczyków. Powyższe informacje po części tłumaczą, dlaczego instytucje i organizacje pozarządowe (NGO-s) nie zaangażowały się w początkowej fazie protestów, które $\mathrm{w}$ pierwotnym stadium były raczej spontaniczną mobilizacją.

Omówione powyżej kwestie tworzą podstawy pozwalające na zastosowanie metodologii koniunkturalnej przyczynowości ${ }^{23}$. Termin „koniunkturalny” należy rozumieć następująco. Oddzielne, ale powiązane wspólnym celem elementy, w połączeniu ze sobą stanowią jedną zdeterminowaną całość. Innymi słowy, dwa lub więcej znaczących komponentów, które miały miejsce w przeszłości, zderzają się ze sobą w określonym momencie. Zachodzi między nimi interakcja i na jej mocy tworzy się zgrana jedność. Tak zintegrowane elementy nadają określony kierunek dalszym działaniom. Zważywszy to, jak Koreańczycy postrzegają amerykańską hegemonię oraz ile znaczy dla nich spożywanie wołowiny, można wysnuć poniższy wniosek. Te czynniki nie są przypadkowe oraz są ze sobą silnie związane. Brzemienna w skutkach decyzja wywarła nieprzewidywane konsekwencje dla Lee Myung-baka i jego rządu. Jednakże nacjonalizm i kultura jedzenia nie mają ani logicznego związku przyczynowo-skutkowego, ani nie stanowią nieodzownych lub odpowiednich warunków, które mogłyby skutkować takimi konsekwencjami.

23 J. Mahoney, Path Dependence in Historical Sociology, „Theory and Society” 2000, nr 4, s. 527-528. 
Dominik Wróblewski - Wyzwania konserwatywnej polityki...

W niniejszej analizie, aby właściwie zrozumieć antyamerykańskie, a konkretniej rzecz ujmując, antywołowinowe protesty, najpierw został poddany analizie przebieg ruchów społecznych zarówno przed jak i po wygraniu wyborów przez opcję konserwatywną. Potem wyjaśniono, jak koreański nacjonalizm i kultura jedzenia zareagowały na poczucie zagrożenia spowodowanego chorobą szalonych krów, którą miała być skażona amerykańska wołowina.

\section{Ruch społeczny a nowe konserwatywne rządy}

W Korei ruch społeczny i opozycja polityczna ukształtowały się w tym samym momencie. Za czasów rządów autorytarnych, najpierw Lee Syng-mana potem Parka Chung-hee i Chun Doo-hwana, nawzajem wspierały się i wzmacniały swoją działalność. W czerwcu 1987 r., podczas rządów Chun Doo-hwana, doszło do prodemokratycznego powstania. Cały kraj zalała fala pokojowych manifestacji, które nie zostały brutalnie stłumione, jak poprzednie ${ }^{24}$. Podczas masowych wystąpień, w których większość stanowili studenci, Chun Doo-hwan niespodziewanie ustąpił wobec żądań opozycji. Doprowadziło to do nowej sytuacji, w której prodemokraci i rząd zaczęli wspólnie ustanawiać demokrację w Korei. W pewnym sensie masowe protesty czerwcowe zmusiły Roh Tae-woo do zaakceptowania demokratycznych żądań opozycji, jeżeli w późniejszym czasie, co z resztą zdają się potwierdzać przyszłe wydarzenia, chciałby pełnić funkcję prezydenta Republiki Korei. Notabene, sam Roh Tae-woo przedłożył deklarację demokratycznych przemian jako właściwy sposób na rozwiązanie ówczesnego kryzysu politycznego w państwie. Ponadto opowiedział się za demokratycznym systemem politycznym, a autorytaryzm uznał za ustrój bez przyszłości. Rozpoczęto prace nad nową konstytucją,

${ }^{24}$ Chun Doo-hwan i jego poplecznicy rozważali wprowadzenie stanu wojennego. Propozycja spotkała się ze zdecydowanym sprzeciwem Roh Tae-woo, który zaczął wyrastać na pierwszoplanową postać. G. Strnad, Południowokoreańska droga do demokracji, Toruń 2010, s. 158-165. 
która zagwarantowała szereg swobód obywatelskich i szerokie prawa demokratyczne ${ }^{25}$.

Trzeba zaznaczyć, że od 2. połowy lat 80 . XX w. autorytarny reżim starał się jednocześnie uporać $\mathrm{z}$ dwiema kwestiami. W sferze polityki rząd próbował wygrać wysoko konkurencyjną walkę z prodemokratyczną opozycją i ze studentami, którzy coraz głośniej domagali się autonomii koreańskich uniwersytetów oraz zmagał się z politycznym wpływem na społeczne niezadowolenie.

Nie bez znaczenia dla danej tematyki jest kwestia gwałtownej industrializacji kraju, która posłużyła za silny czynnik motywujący wszelkie ruchy społeczne w Korei. Demonstrantami byli pracownicy wyczerpani polityką wyzysku, rolnicy straszeni importowanymi produktami rolniczymi i mieszkańcy miast, zmagający się z ciągle rosnącym poziomem zanieczyszczenia środowiska. W związku z tym polityczny prestiż ruchów społecznych w Korei zdecydowanie różni się od prestiżu takich ruchów innych narodów. Koreańskie demonstracje uważa się za zbyt radykalnie ideologicznie. $\mathrm{W}$ dodatku, w kwestiach organizacyjnych nie są powiązane $\mathrm{z}$ żadną partią polityczną. Powszechne jest odseparowywanie politycznych kontekstów od działalności manifestantów. Od lat 70. XX w. koreańscy dysydenci tworzą minjung 26 - ruch, za pomocą którego wyrażano sprzeciw wobec autorytarnych rządów junty wojskowej. Równocześnie ta forma sprzeciwu pełniła funkcję ruchu opartego na przynależności klasowej27 oraz aktywności nacjonalistycznej ${ }^{28}$, kwestionującej porządek narzucony przez USA podczas zimnej wojny.

25 Nastąpił powrót do demokratyzacji życia politycznego i publicznego, zakazanych od tzw. rewolucji majowej, po której nastał czas rządów junty wojskowej; ibidem, s. 73-76.

${ }^{26}$ Minjung dosłownie oznacza ludzi lub masy.

27 Koo Hagen, The State, Minjung, and the Working Class in South Korea, [w:] Koo Hagen (red.), State and Society in Contemporary Korea, New York 1993, s. 145.

28 Kang Man-gil, Contemporary Nationalist Movements and the Minjung, [w:] K. M. Wells (red.), South Korea's Minjung Movement: The Culture and Politics of Dissidence, Honolulu 1995, s. 31-38. 
Dominik Wróblewski - Wyzwania konserwatywnej polityki...

Warto podkreślić, że koreańskie demonstracje nie były w żadnej mierze motywowane świadomością ofiar systemu autorytarnego. Z kolei rząd w Seulu można byłoby obarczyć chęcią zadośćuczynienia za wszystkie lata politycznego wyzysku czy degradacji środowiska.

Pod koniec lat 80. XX w. radykalny odłam minjung przygotował grunt pod nowy ruch społeczny. Założona w 1989 r. Citizens' Coalition for Economic Justice (CCEJ) ${ }^{29}$ kierowana była głównie przez średnią klasę profesjonalistów. Dzięki zapożyczeniu reformistycznego podejścia CCEJ stała się najbardziej wpływową organizacją społeczną w latach 90. XX w. Należy mieć także na względzie niewiarygodny sukces kampanii antykorupcyjnej wymierzonej w konkretnych polityków ${ }^{30}$, która w dokładny w sposób obrazuje niezależną postawę koreańskich aktywistów względem wszelkich partii politycznych. Ponad 400 organizacji pozarządowych wzięło udział w tym przedsięwzięciu, skutkiem czego 56 na 86 kandydatów oskarżonych o nadużycia w łamaniu praw człowieka lub korupcję poniosło porażkę podczas przyszłych wyborów ${ }^{31}$.

Pomimo partyjno-społecznych konfiguracji w państwie koreańskim nastąpiła swoista ewolucja społecznych manifestacji zaraz po tym, jak prodemokratyczna polityczna opozycja doszła do władzy. W 1998 r. Kim Dae-jung wygrał wybory prezydenckie, a jego postę-

${ }^{29}$ Citizens' Coalition for Economic Justice (CCEJ), organizacja społeczna założona w 1989 r., w Korei. Działa na rzecz zjednoczenia obu państw koreańskich, demokratycznego i społecznego rozwoju, gospodarczej sprawiedliwości i ochrony środowiska. Obecnie liczy ponad 35 tys. członków. Jej struktura podzielona jest na 35 oddziałów. CCEJ osiągnęła znaczne sukcesy w dziedzinie edukacji, rozwoju alternatyw w polityce; ponadto wspiera legalne reformy. Organizacja odpowiedzialna jest za organizowanie i przeprowadzanie publicznych dysput i audycji oraz informuje prasę o obawach społeczeństwa. CCEJ rozszerzyła działalność regionalną na sferę globalną. W 2003 r. otrzymała nagrodę Right Livelihood Award za osiągnięcia w walce o społeczną i gospodarczą sprawiedliwość. Citizens' Coalition for Economic Justice, http://www.ccej.or.kr/English [dostęp: 24-05-2016].

30 Kampania odbyła się w 2000 r. pod nazwą: 2000 Blacklisting Campaign against Corrupt Politicians; Cho Hee-yeon, L. Surendra, Cho Hyo-je (red.), Contemporary South Korean Society. A Critical Perspective, London 2013, s. 72.

${ }^{31}$ Kim Sun-hyuk, Democratization and Social Movements in South Korea: A Civil Society Perspective, [w:] J. Broadbent, V. Brockman (red.), East Asian Social Movements: Power, Protest, and Change in a Dynamic Region, New York 2011, s. 141-156. 
powe rządy zapoczątkowały serię reform politycznych i ekonomicznych ${ }^{32}$. W 2003 r. prezydentem został Roh Moo-hyun, którego gabinet nazwano rządem uczestniczącym. Nadto wielu aktywistów aranżujących ruchy społeczne w kraju zostało zatrudnionych w jego aparacie administracji. W latach 1998-2007 widoczna była integracja roszczeń społecznych z rządowymi programami.

W tamtym okresie stopniowo zatrudniano aktywistów na stanowiskach rządowych ${ }^{33}$. Wśród nich były osoby pracujące wcześniej w People's Solidarity for Participatory Democracy (PSPD) ${ }^{34}$. Z kolei CCEJ posiadała 55 członków gabinetu członków za kadencji dwóch postępowych rządów 35 .

W dodatku, zaangażowanie powyższych osób umożliwiło przeprowadzenie szeregu reform $\mathrm{w}$ sferze politycznej i gospodarczej. Jest to fakt niezaprzeczalny. Jednakże ich małżeństwa z politykami oraz przyjacielskie stosunki z rządem są kontrowersyjne. $\mathrm{W}$ efekcie nastąpił drastyczny spadek popularności koreańskich organizacji pozarządowych. Według sondaży przeprowadzonych między 2005 a 2007 r.

32 Kim Dae-jung zapowiedział okres potu i łez. Innymi słowy, chodziło o okres, w którym Korea miała wejść na drogę licznych wyrzeczeń. Gabinet ówczesnego prezydenta nazywano rządem narodu. Za jego czasów przeprowadzono kolejne reformy gospodarcze oraz zrestrukturyzowano 4 sektory: korporacyjny, finansowy, pracowniczy i publiczny. Zadbano również o przyciąganie zagranicznych inwestycji do Korei oraz podjęto próbę stworzenia państwa opiekuńczego z efektywniejszą niż w poprzednich latach opieką społeczną. W. J. Dziak, G. Strnad, Republika Korei. Zarys ewolucji systemu politycznego, Instytut Studiów Politycznych PAN, Collegium Civitas, Warszawa 2011, s. 221-225.

33 Zatrudniono 73 urzędników i 98 aktywistów; Lee Ho-yeon, Park Tae-yong, Civil Participation in the Making of a New Regulatory State in Korea: 1998-2008, „Korea Observer" 2009, nr 3, s. 461-493.

34 People's Solidarity for Participatory Democracy (PSPD), organizacja pozarządowa, założona w Korei w 1994 r., pod nazwą Citizens' Solidarity for Participatory Democracy and Human Rights. Początkowo liczba członków nie przekraczała 200. Od 2004 r., PSPD uzyskała specjalny status opiniodawczy przy ONZ ECOSOC. Na mocy statusu wspiera działania różnych organów pomocniczych ONZ, tj. Rada Praw Człowieka ONZ. PSPD w głównej mierze jest odpowiedzialna za kampanię antykorupcyjną w Korei z 2000 r.; People's Solidarity for Participatory Democracy, http://www. peoplepower21.org/English [dostęp 24.05.2016]. 493.

${ }^{35}$ Lee Ho-yeon, Park Tae-yong, Civil Participation in the Making..., op. cit., s. 461- 
Dominik Wróblewski - Wyzwania konserwatywnej polityki...

JoongAng Daily, wraz z CCEJ i PSPD jedna z popularniejszych tego typu organizacji, stopniowo traciła zaufanie obywateli swojego kraju ${ }^{36}$. W trakcie domagania się przez społeczeństwo i opozycję impeachmentu Roh Moo-hyuna ${ }^{37}$ w 2004 r. koreańskie NGO-s stanowczo opowiedziały się za ówczesnym prezydentem ${ }^{38}$. Ta sytuacja wyraźnie świadczy o silnych relacjach z ekipą rządzącą. Co więcej, owa reakcja nie była żadnym zaskoczeniem.

Kolejna zmiana relacji na linii rząd-demonstranci-NGO-s nastąpiła w 2007 r., kiedy Lee Myung-bak wygrał wybory prezydenckie. Konserwatywna administracja Lee na czele $\mathrm{z}$ nim samym odniosła walne zwycięstwo w walce o liczbę mandatów, co potencjalnie ułatwiało podejmowanie decyzji. Piętnowano poprzednie okresy rządów, które określono straconą dekadą i realizowano odmienny program niż w latach ubiegłych ${ }^{39}$. Próba naprawy wybrakowanych reform wcześ-

36 Przeprowadzone w tych latach sondaże wyraźnie wskazują na spadek publicznego zaufania do NGO-s wśród koreańskiego społeczeństwa. Wyniki opublikowano we wszystkich ważniejszych koreańskich gazetach, więc każdy miał do nich swobodny dostęp. Warto zwrócić na nie uwagę, ponieważ na ich podstawie dokładnie widać, jak w przeciągu krótkiego okresu zmieniła się percepcja walczących o demokrację organizacji pozarządowych. Kim Eui-young, The Limits of NGO-Government Relations in South Korea, „Asian Survey” 2009, nr 5, s. 873-894.

37 W 2003 r. Roh Moo-hyun został postawiony w stan oskarżenia pod zarzutem przyjęcia nielegalnych funduszy na realizację kampanii prezydenckiej. Oskarżenia potęgował fakt nieprzyznania się do ewidentnego naruszenia prawa oraz deklarowanie oficjalnego poparcia dla Naszej Otwartej Partii, wspierającej prezydenta. Roh, mając na względzie swoją polityczną przyszłość, zasugerował podanie się do dymisji, jeśli wspomniana partia nie odniesie sukcesu w nadchodzących wyborach parlamentarnych. Polityczne zaangażowanie prezydenta wykorzystała opozycyjna Wielka Partia Narodowa i Demokratyczna Partia Nowego Milenium. Obie partie przegłosowały wniosek o trybunał stanu dla prezydenta. Było to historyczne i bezprecedensowe wydarzenie w dziejach kraju. Dodatkowo społeczeństwo domagało się konstruktywnych reform gospodarczych i dyskredytowano prowadzoną przez Roha politykę wobec Korei Północnej, nazywając ją polityką ciągłych ustępstw. Szalę goryczy przelała ustawa reformująca media, którą społeczeństwo odebrało jako atak na wolność słowa i prasy. Ustawa zakładała ograniczenie do $60 \%$ udziałów największych gazet w rynku prasowym; W. J. Dziak, G. Strnad, Republika Korei..., op. cit., s. 240-242, 247.

38 South Korean President Impeached, „BBC” z dn. 12.03.2004, http://news.bbc.co. uk/2/hi/asia-pacific/3504026.stm [dostęp: 24-05-2016].

${ }^{39}$ Lee Myung-bak i jego gabinet realizował swoją politykę pod następującym hasłem: Wszystko tylko nie Roh. 
niejszych rządów była jedną z przyczyn powstania nowej fali oporu w ruchu społecznym.

Warto zwrócić uwagę na pewien fakt. Otóż czas jest czynnikiem, który znacznie wpłynął na politykę zagraniczną Republiki Korei dotyczącą amerykańskiej wołowiny. Lee Myung-bak, sprawując urząd prezydenta od dwóch miesięcy, podjął nagłą zmianę w tej sprawie. Następstwem był masowy sprzeciw społeczeństwa i próba wykorzystania tej sytuacji przez jego politycznych przeciwników. Okazało się, że ten problem stanowił pierwsze krytyczne wyzwanie, przed którym stanął prezydent i jego gabinet. Co istotne, wydarzenia dotyczące spornego zagadnienia, czyli masowe wystąpienia społeczne, można, a nawet należy porównać do wystąpień za czasów autorytarnych reżimów.

Dalsza polityka wobec amerykańskiego mięsa została bezsprzecznie zdeterminowana przez strukturalne uwarunkowania. W zakresie relacji partyjnych z ruchami społecznymi koreańskie NGO-s plasują się na silnej pozycji, charakteryzują się niefrakcyjnością i związaną z nią lojalnością, a mobilizacja członków jest stosunkowo szybka. Co ciekawe, stosunek wobec importowanego artykułu niejako tłumaczy się ich pozycją w kraju. Trzeba wyraźnie podkreślić, że protesty spontanicznie zainicjowano za pomocą portali internetowych, jeszcze zanim organizacje pozarządowe przejęły rolę lidera manifestacji ${ }^{40}$. Jednakże NGO-s wspólnie z koreańskimi partiami politycznymi nie odgrywały w nich ważnej roli.

\section{Koreańskie wspólnoty, ich przekonania i zagrożenia}

Poniżej zostanie wyjaśniona kwestia koreańskiego kulturowego wymiaru nacjonalizmu i jedzenia. Wprawdzie amerykański produkt może smakować Koreańczykom, ale znaczenie mięsa wołowego na-

\footnotetext{
40 Koreańskie NGO-s przejęły tę funkcję dopiero na przełomie czerwca i lipca 2008 r.; Ho Ming-sho, Hong Chen-shuo, Challenging New Conservative Regimes in South Korea and Taiwan. Comparison of the Anti-American Beef Protests, „Asian Survey” 2012, nr 4, s. 652.
} 
Dominik Wróblewski - Wyzwania konserwatywnej polityki...

leży rozpatrywać poprzez ich narodową mentalność. Incydent z wołowiną uznano za amerykańską inwazję na suwerenność państwa. Podczas licznych demonstracji w Seulu powszechne były plakaty odnoszące się do narodowych, czytaj - koreańskich, wartości. Przykładowo bezradna gospodyni domowa przeciwstawiająca się statkom wyładowanym amerykańskimi krowami, które zostały przekreślone na czerwono. Popularne były również hasła Our Home Opposes U.S. Beef Imports. Ponadto, rozpowszechniono obrazek, na którym widnieje postać Amerykanina-imperialisty, obwieszonego różnego rodzaju bronią palną. To bardzo wymowny symbol, dosadnie obrazujący, że amerykańska wołowina to śmiercionośna broń, a nie produkt jadalny. Ów plakat wykorzystano podczas demonstracji w całym kraju.

Pod względem struktury kulturowej, nacjonalizm funkcjonuje w obrębie indywidualnej, bądź kolektywnej tożsamości, która często wzmacniana jest poczuciem zagrożenia z zewnątrz. Ponadto, istnienie nieprzyjaznego, bezpośrednio wrogiego obcego-innego, stanowi czynnik zacieśniający wewnętrzne więzi oraz jednoczy różne elementy niepowiązane ze sobą. Dlatego antyamerykańskie protesty z 2008 r., miały cechy podobne do tych, które towarzyszyły demonstracjom przeciw rządom autorytarnym ${ }^{41}$.

Podczas zimnej wojny, kraj musiał jednocześnie poradzić sobie z dwoma problemami. Z komunistycznym zagrożeniem z Północy i z gwałtownym rozwojem gospodarczym. Konsekwencją była utrata wolności politycznej i naruszenie praw człowieka, co spotkało się z poparciem USA. Ho Ming-sho i Hong Chen-shuo stwierdzają, że do masakry w Kwangju w 1980 r., doszło tylko dlatego, że wojskowe zwierzchnictwo USA pozwoliło na rozlokowanie koreańskich wojsk ${ }^{42}$. Powyższy incydent na stałe zraził koreański ruch prodemokratyczny do Amerykanów. Po tych wydarzeniach, środowiska naukowe w kraju poddały pod wszelką wątpliwość przyjacielską postawę USA do Korei oraz skrytykowały amerykańskie poparcie dla autorytarnego reżi-

\footnotetext{
${ }^{41}$ Oh Chang-hun, Arrington C., Democratization and Changing Anti-American Sentiments in South Korea, „Asian Survey” 2007, nr 2, s. 327-350.

42 Ho Ming-sho, Hong Chen-shuo, Challenging New Conservative..., op. cit., s. 653.
} 
$\mathrm{mu}^{43}$. Ponadto, wyrażono ogromne rozczarowanie niepowodzeniami $\mathrm{w}$ ustanowieniu procesu demokratyzacji.

Trzeba wspomnieć, że Koreańczycy mają ambiwalentny stosunek do USA. Doceniają ich rolę, jaką odegrały w ustanowieniu demokratycznego państwa w południowej części Półwyspu oraz cenią obecny sojusz militarny. Jednakże amerykańskie bazy wojskowe, rozlokowane na terytorium Republiki Korei, wzbudzają wiele kontrowersji. Wszelkie incydenty związane $\mathrm{z}$ amerykańskimi żołnierzami ${ }^{44}$ są nagłaśniane w mediach. Skutkują jedynie nasilaniem się antyamerykańskiego wizerunku oraz społecznej nieufności i, w szczególności, niechęci do USA. Równocześnie wzrasta przekonanie o zjednoczeniu obu państw koreańskich bez żadnych ingerencji ze strony państw obcych. Z pewnością ciekawą kwestią jest zmiana wizerunku wobec Korei Północnej. Koniec zimnej wojny i wpływ Słonecznej Politykii ${ }^{45}$ sprawił, że naród koreański zaczął postrzegać Północ, jako mniej zagrażającą Południu. Z kolei, powyższy pogląd nie jest akceptowany przez USA.

43 Od momentu przybycia amerykańskich żołnierzy na terytorium Korei, aż do lat 80. XX w., przedstawiany w mediach wizerunek USA był jednoznacznie pozytywny. Kraj traktowano nawet jako starszego brata, który przedkłada bezpieczeństwo Korei nad własnymi interesami w regionie. Nastroje społeczne Koreańczyków świadczyły o traktowaniu USA za gwarant bezpieczeństwa przed agresją ze strony komunistycznej Północnej. Zmiana polityki zagranicznej USA - unormowanie stosunków z Chińską Republiką Ludową i ZSRR oraz złagodzenie polityki wobec państw komunistycznych, w szczególności wobec Korei Północnej, wywołały obawy wśród społeczeństwa Korei. Od tego momentu narastała krytyka wobec polityki zagranicznej USA; Zob. Yankees Go Home, http://www.soulinseoul.pl/2015/08/02/yankees-go-home/ [dostęp: 24-05-2016].

${ }^{44}$ Według przeciętnego Koreańczyka amerykański żołnierz dużo imprezuje, przejawia gen alkoholika, jest głośny, chamowaty i ordynarny oraz zachowuje się nieodpowiednio względem kobiet, przejawiając wobec nich postawę roszczeniową; Ibidem.

45 Słoneczna Polityka - polityka Korei wobec Północnego sąsiada. Jej głównym zadaniem była poprawa stosunków obu państw koreańskich i niejako zmuszenie KRL-D do współpracy polityczno-gospodarczej. Twórcą jest Kim Dae-jung, który mając na celu działania w zakresie gospodarki, polityki i dyplomacji chciał ułatwić zjednoczenie Półwyspu Koreańskiego w odległej perspektywie. Politykę kontynuował Roh Moo-hyun. Jednakże, od czasu prezydentury Lee Myung-baka nastąpił zwrot w stosunkach dwustronnych, który był kontynuowany przez Park Geun-hye; W. J. Dziak, G. Strnad, Republika Korei..., op. cit., s. 229-231. 
Dominik Wróblewski - Wyzwania konserwatywnej polityki...

Przejście od autorytarności do demokracji w Korei spowodowało powstanie dwóch opcji politycznych. Pierwsza, konserwatywna zachowała antykomunistyczną i proamerykańską ideologię. Natomiast druga reformatorska opowiedziała się za perspektywą biegunowości świata ${ }^{46}$. Kim Dae-jung po zwycięstwie w wyborach prezydenckich, wraz z opcją reformatorską dążył do zmiany w sferze polityki zagranicznej. W związku z tym zapoczątkowano Słoneczną Politykę, która miała na celu poprawę obopólnych relacji oraz współpracę polityczno-gospodarczą na Półwyspie Koreańskim. W 2000 r. odbyło się pierwsze historyczne spotkanie na szczeblu prezydencjalnym między Kim Dae-jungiem a Kim Dzong-ilem, co świadczy o kulminacji dotychczasowych działań. Spotkanie uznano za nową narodową politykę, na mocy której wewnętrzne koreańskie relacje stały się możliwe bez żadnej mediacji ze strony USA. Ponadto, na Półwyspie nastąpił proces de-eskalacji napięcia, powiązany z objęciem urzędu prezydenta przez George'a W. Busha. Jednakże jego działania stanowiły główny powód braku zaufania Koreańczyków względem USA. Od 2002 r., George W. Bush prowadził politykę silnej ręki wobec komunistycznego reżimu. Równocześnie, wobec Korei Północnej używał sformułowania „oś zła”, posądzał ją o wspieranie globalnego terroryzmu i produkcję broni masowego rażenia. Koreańskie społeczeństwo negatywnie zareagowało na wspomniane porównania i oskarżenia, ponieważ poważnie urażono ich narodowe poczucie tożsamości. Jak wykazały sondaże, Koreańczycy deklarowali pozytywny stosunek do poprawy relacji dyplomatycznych między oboma państwami koreańskimi i do pokojowego, ale stopniowego procesu zjednoczenia Półwyspu Koreańskiego, bez żadnych ingerencji państw zagranicznych. Nadto, oskarżenia pod adresem Korei Północnej uznano za niesprawiedliwe i w większości niemające podstaw prawnych. Poddano również pod wątpliwość działania rządu USA mające na celu regionalne bezpieczeństwo. W trakcie

46 Lee Sook-jong, Democratization and Polarization in Korean Society, „Asian Perspective" 2005, nr 3, s. 104. 
wizyty George'a W. Busha, odbył się protest radykalnych koreańskich studentów przed amerykańską Izbą Handlową w Korei ${ }^{47}$.

Również przepaść międzypokoleniowa odgrywa dużą rolę w percepcji USA. Starsze pokolenie Koreańczyków, które doświadczyło wojny koreańskiej, wyraża wdzięczną postawę, uznaje za gwarant stabilizacji społecznej i wzrostu gospodarczego. Natomiast Koreańczycy urodzeni w latach 60 . XX w. i później, całkowicie odmiennie postrzegają USA. Pokolenie prodemokratyczne walczące $\mathrm{z}$ autorytarnym systemem uważa USA za niesprzyjającego opiekuna. W styczniu $2003 \mathrm{r}$. powyższą przepaść ukazały zorganizowane przez gazetę Chungang Ilbo sondaże, odnoszące się do United States Forces Korea (USFK) ${ }^{48}$. Tylko 29.5\% respondentów w wieku 20-29 lat akceptowało status USFK, podczas gdy, aż 51.5\% ankietowanych po 50. roku życia uznało ją za niezbędną. Z pierwszej grupy osób - 15.4\%, opowiedziało się za całkowitym wycofaniem lub dość znaczną redukcją wojsk amerykańskich. Natomiast z drugiej grupy wiekowej tylko 8\% opowiedziało się za powyższą opcją ${ }^{49}$. Niemniej jednak widoczne są narastające antyamerykańskie nastroje wśród młodego pokolenia. Co więcej, intensywność takich nastrojów stopniowo narasta w ostatnich latach i znacząco wpływała na rozwój relacji wewnątrz Półwyspu Koreańskiego ${ }^{50}$.

Argumentem poświadczającym powyższe, była zgoda Korei Północnej na ukazanie części kontrowersyjnego nuklearnego kompleksu

47 Kim Seung-hwan, Anti-Americanism in Korea, „Washington Quarterly” 2002, nr 1 , s. 111.

48 United States Forces Korea (USFK), jednostka dowództwa United States Pacific Command, założona w $1957 \mathrm{r}$. W przypadku zagrożenia, wojska USA zostaną wysłane na terytorium Korei poprzez USFK. Do najważniejszych celów należy wspieranie działań i manewrów militarnych wojsk ONZ oraz wspólna z siłami USA, koordynacja i planowanie działań w ramach United States Pacific Command. USFK organizuje, trenuje i dostarcza wyposażenie wojskom amerykańskim na terenie Półwyspu Koreańskiego; United States Forces Korea, http://www.usfk.mil/ [dostęp: 24-05-2016].

${ }^{49}$ Kim Jin-wung, Ambivalent Allies: Recent South Korean Perceptions of the United States Forces Korea (USFK), „Asian Affairs” 2004, nr 4, s. 273.

50 Jung Heon-joo, The Rise and Fall of Anti-American Sentiment in South Korea: Deconstructing Hegemonic Ideas and Threat Perception, „Asian Survey” 2010, nr 5, s. 946-964; obecnie relacje między dwoma państwami uległy pogorszeniu ze względu na prowokacyjną politykę Korei Północnej. 
Dominik Wróblewski - Wyzwania konserwatywnej polityki...

i pozwolenie na międzynarodową kontrolę. W odpowiedzi Południe zadeklarowało ogromne poczucie bezpieczeństwa. Z kolei, wspomniana kwestia jest jednym z czynników, który skutkował manifestacjami przeciwko wołowinie z USA. Niestety, od 2009 r., nastąpił zwrot w północnokoreańskiej polityce, który trwa po dziś dzień. Północ powróciła do wrogiego dialogu i konfrontacyjnej polityki względem południowego sąsiada. Reaktywowała program nuklearny i zainicjowała kilkanaście militarnych manewrów. W konsekwencji, w Korei nastąpił wzrost przychylnego nastawienia względem USA. Wskazują na to wyniki sondaży przeprowadzonych przez Pew Reaserch Center ${ }^{51}$. Po raz kolejny czas odegrał tu ważną rolę. Gdyby Lee Myung-bak wznowił import amerykańskiej wołowiny w 2009, a nie w 2008 r., to zagrożenie ze strony wrogiej Północy stanowiłoby twardy argument, a przeciwnicy prezydenta mieliby mniejsze pole manewru w wyrażaniu antyamerykańskiej postawy.

Łatwo zrozumieć wahania nastrojów wobec USA i pośpieszną decyzję prezydenta, postrzegając je przez pryzmat koreańskiego nacjonalizmu. Warto zwrócić również uwagę, na to, że cały incydent obfituje w stereotypowe oskarżenia. Lee Myung-bak wraz ze swoją konserwatywną opcją został obwiniony o poświęcanie dobra własnych obywateli, żeby za wszelką cenę zadowolić Amerykanów. Niespotykana na tak ogromną skalę aktywność społeczeństwa, w tym duży udział licealistów, świadczy o szerokiej rewizji nastrojów wobec USA. W następstwie ówczesny prezydent został zmuszony do wygłoszenia upokarzających publicznych przeprosin i do reorganizacji swojego gabinetu.

Próbą poprawienia wizerunku prezydenta i jego rządu, był incydent z przekąskami sprowadzanymi z Chin. We wrześniu 2008 r., koreańska Agencja Żywności i Leków (Korea Food and Drug Administration, KFDA), ogłosiła, że przekąski zawierały szkodliwe dla zdrowia duże ilości melaminy. Na skutek komunikatu, wstrzymano ich

\footnotetext{
51 Pew Research Center, Obama More Popular Abroad than at Home, Global Image of U.S. Continues to Benefit: 22-Nation Pew Global Attitudes Survey, s. 25-33.
} 
import w celu dokładniejszego przeprowadzenia badań ${ }^{52}$. Następnego dnia po ogłoszeniu informacji, Lee Myung-bak udał się z wizytą do siedziby KFDA, aby zademonstrować swoje zobowiązanie i zaangażowanie w ochronę zdrowia obywateli swojego kraju przed produktami zawierającymi trujące związki chemiczne ${ }^{53}$.

Jednakże opinia publiczna uznała działania rządu za pozorne. Trzeba nadmienić, że od momentu ujawnienia skandalicznych wiadomości, gabinet prezydenta monitorował zawartość melaminy w żywności. Zachowanie rządu nie zostało zinterpretowane jako zaniedbanie. Niemniej jednak 29 września 2008 r., odbyła się demonstracja na ulicach w Seulu, podczas której uczestnicy żądali zaostrzenia kontroli żywności. Co trzeba podkreślić, manifestanci nie postrzegali owego kryzysu, jako dowodu kolejnej porażki rządu ${ }^{54}$. Aczkolwiek, opozycja podjęła próby zrzucenia politycznej odpowiedzialności na rząd Lee Myung-baka.

Powyższa analiza jest potrzebna dla dokładnego i w miarę przejrzystego zrozumienia przestudiowanego problemu. Na pierwszy rzut oka są to czynniki, które nie mają znaczenia, lecz po ich dokładniejszym zweryfikowaniu okazuje się, że stanowią ważny element łączący wydarzenia z $2008 \mathrm{r}$.

\section{Symboliczny status wołowiny w Korei}

Nawiązując do nacjonalizmu, status wołowiny w koreańskiej kulturze jedzenia miał wpływ na negatywne odebranie kontrowersyjnej kwestii przez społeczeństwo. Najwyraźniej, im więcej wołowiny spo-

52 Dokładniej mówiąc, KFDA ogłosiła informacje 25 września 2008 r.; Toxic Substance Found in Chinese-Made Korean Snacks, „Chosun Ilbo” z dn. 25.09.2009, http://english.chosun.com/site/data/html_dir/2008/09/25/2008092561011.html [dostęp: 24-05-2016].

53 Korea JoongAng Daily, http://koreajoongangdaily.joins.com/news/article/Arti cle.aspx?aid=2895391 [dostęp: 24-05-2016].

${ }^{54}$ Consumers Shun Made-in-China Food Products, „Korea Times” z dn. 29.09.2008, http://www.koreatimes.co.kr/www/news/nation/2008/09/117_31847.html [dostęp: 24-05-2016]. 
Dominik Wróblewski - Wyzwania konserwatywnej polityki...

żywa dany naród, tym zwiększa się prawdopodobieństwo udziału w protestach licznej grupy osób. W szczególności, jeżeli poczucie zagrożenia dla zdrowia człowieka zostanie zachwiane. Takim z pewnością było skażone pożywienie. Odnosząc się do badań przeprowadzonych przez Korea Meat Trade Association (KMTA), w 2007 r., przeciętny mieszkaniec Korei spożywał średnio $7.61 \mathrm{~kg}$ wołowiny55. Z tego też powodu, konsumentów tak bardzo zaalarmowało skażone importowane mięso. Wprawdzie jakościowe dane nie są w stanie udowodnić symbolicznego znaczenia pożywienia; niemniej jednak status wołowiny oraz pozycja jej lokalnych wytwórców stanowią najważniejsze czynniki mające niekwestionowany wpływ na interpretowanie poczucia zagrożenia przez konsumentów.

Notabene, kulinarne wykorzystanie wołowiny przez Koreańczyków jest też bardzo ważne. W tradycyjnej kuchni koreańskiej omawiany produkt uważany jest za jeden z najbardziej wartościowych produktów bogatych w białko. Za przykład może posłużyć bulgogi, czy miyeokguk56, traktowane jako odżywczy składnik, który często spożywają matki zaraz po urodzeniu dziecka oraz młode dzieci. Silne skojarzenie obu potraw z narodzinami sprawiło, że dania stały się popularnym posiłkiem podczas obchodzenia urodzin wśród młodych Koreańczyków.

Oprócz tego istotna pozycja wołowiny odegrała kluczową rolę i dostarczyła solidne podstawy pod antyamerykańskie protesty. Znamiennym obrazkiem demonstracji jest widok dużej liczby młodych matek trzymających w ramionach własne dzieci. Wysoko stylizowana dramatyzacja macierzyństwa ukazuje wyraźnie poufny i osobisty związek

55 Korea Meat Trade Association, Consumption, http://www.kmta.or.kr/eng/sub41.html?scode=6\&kej=eng [dostęp: 24-05-2016].

56 Bulgogi - marynowana, pieczona na grillu wołowina. Natomiast miyeokguk, to zupa z morskich wodorostów miyeok z gotowaną mieloną wołowiną. Oba dania należą do repertuaru smacznych tradycyjnych potraw kuchni koreańskiej. W ciągu ostatnich lat Ministerstwo Kultury, Sportu i Turystyki Republiki Korei wpisało bulgogi na listę niematerialnego dziedzictwa Korei obok kimchi, hangul - koreański alfabet czy Taekwondo; South Korea's Ministry of Culture, Sport and Tourism, http://www.mct. go.kr/html/symbolImg/eng/bulgogi/sec01.html [dostęp: 24-05-2016]. 
między wołowiną a rodzinnymi nawykami żywieniowymi ${ }^{57}$. Dla koreańskich mam, lekkomyślna decyzja Lee Myung-baka zagrażała zdrowiu i dobrostanowi ich pociech.

Dodatkowo należy zwrócić uwagę na czynnik ekonomiczny, a dokładniej rzecz ujmując, na pozycję lokalnych producentów wołowiny, których w szczególności dotyczyła zapowiadana zmiana. Od 1989 r., w Korei popularny stał się ruch shintobul-i (dosłownie jedność ciała i ziemi), promujący i nawołujący do idei spożywania żywności wyprodukowanej w kraju. Równolegle, narastał patronat nad rolnikami próbującymi znaleźć swoje miejsce w zliberalizowanym rynku. $Z$ biegiem czasu, shintobul-i przybrał bardziej integralny wymiar narodowej tożsamości. W swojej idei nawiązywał choćby do tradycyjnych potraw, a przeciętny Koreańczyk permanentnie został dumnym mecenasem ogromnej różnorodności narodowych wartości i produktów ${ }^{58}$. Oczywiście, wywyższanie lokalnych potraw nad importowanymi skutkowało podniesieniem wartości rynkowej koreańskiej wołowiny ${ }^{59}$. Jednakże dość wysoka cena lokalnego produktu nie osłabiła narodowego sentymentu. Równocześnie amerykańską wołowinę uznano za substytut taniego, niezdrowego i małowartościowego mięsa dla masowej rzeszy konsumentów. Jak twierdzi Chae Su-hong, importowana żywność udźwignęła polityczną odpowiedzialnośćc0.

Silna pozycja lokalnego przemysłu mięsa także stanowiła podłoże antyamerykańskich manifestacji. Udział w nich brali zwykli obywatele oraz lokalni producenci wołowiny, którzy dodatkowo wywierali naciski na Lee Myung-baka i jego rząd. 23 maja 2008 r., 8 tys. grupa rolni-

\footnotetext{
57 Chae Su-hong, The Candlelight Protest and the Politics of the Baby Stroller Brigades, „Korea Journal” 2010, nr 3, s. 71-99.

58 Cho Hong-sik, Globalization and National Identity: Shintobul-i, a Case of Cultural Representation of Economic Nationalism, "Journal of International and Area Studies" 2008, nr 1, s. 17-35.

${ }^{59}$ Chodzi o wspomnianą hanwoo, która jest delikatniejsza i sześć razy droższa od importowanej wołowiny z USA.

60 Pomimo licznych protestów, import wołowiny został oficjalnie wznowiony 1 lipca 2008 r. Mięso w głównej mierze trafiło do niedrogich restauracji i szkolnych stołówek. Dlatego między innymi, nie dziwi obecność licealistów w protestach; Chae Su-hong, The Candlelight Protest..., op. cit., s. 71-99.
} 
Dominik Wróblewski - Wyzwania konserwatywnej polityki...

ków zorganizowała protest w seulskim Parku Yeouido. Protestowano też przeciwko FTA zawartej między Koreą a USA i domagano się, aby prezydent spełnił obietnice wyborcze dotyczące rolnictwa. Po zakończeniu demonstracji rolnicy dołączyli do reszty społeczeństwa protestującego na Cheonggye Plaza. Powyższe wydarzenia sygnalizują dobrą współpracę różnych grup oraz poruszają kwestie bezpieczeństwa zdrowia i ochrony żywności61.

\section{Podsumowanie}

Dla postronnych obserwatorów, manifestacje z 2008 r., świadczą o nadzwyczajnym wydarzeniu i bezprecedensowej transformacji wizerunku koreańskiego społeczeństwa na świecie. Intrygujący w omawianej problematyce jest fakt, w którym z pozoru zwyczajna i apolityczna kwestia poruszyła całe społeczeństwo i uruchomiła masową falę antyrządowych demonstracji. W następstwie nowo wybrany prezydent został zmuszony do wygłoszenia upokarzających przeprosin.

Powyżej dokonano wyjaśnienia danego zjawiska, skupiając się na różnych teoriach i przykładach, jak informacje dotyczące opiekuńczych matek lub roli Internetu w protestach. Należy zachować zbalansowane podejście i posiadać sceptyczne nastawienie analizując dany problem. Kwestią problematyczną jest przyjęcie tylko jednego czynnika, zewnętrznego bądź wewnętrznego, który można byłoby uznać za główny element odpowiedzialny za wybuch masowych wystąpień na ulicach Korei. Omawiając powyższy przypadek, niemożliwe jest stwierdzenie, że portale internetowe, jedna grupa społeczna, jedna generacja lub specyficzne cechy społeczne odegrały znaczącą rolę i stanowiły trzon demonstracji. Dlatego tak ważna jest analiza kontekstowa, odnosząca się do kultury. Wówczas można zrozumieć, dlaczego decyzja o wznowieniu importu amerykańskiego produktu doprowadziła do wspomnianych politycznych konsekwencji.

61 Farmers in Massive Protests against FTA with U.S., „Chosun Ilbo” z dn. 23.05. 2008, http://english.chosun.com/site/data/html_dir/2008/05/23/2008052361022. html [dostęp: 24-05-2016]. 
Po pierwsze, koreańską politykę dotyczącą importu wołowiny trzeba interpretować pod kątem procesu demokratyzacji państwa oraz ewolucji aktywności ruchu społecznego, która nastąpiła od momentu prodemokratycznego powstania czerwcowego. Lee Myung-bak i jego konserwatywny gabinet dążył do zmiany kierunku reform, ustanowionych przez poprzednie ekipy rządzące. $\mathrm{W}$ rezultacie wywiązał się konflikt z koreańskimi organizacjami społecznymi i NGO-s. Ponadto, zamierzano znormalizować stosunki wzajemne z USA. Obiecano zniesienie zakazu importu mięsa, ale w zamian domagano się wyrażenia zgody na FTA. Niemniej jednak, podjęcie kontrowersyjnej decyzji zapoczątkowało krytykę rządu oraz falę masowych manifestacji, które postawiły prezydenta pod ścianą. Świadczy o tym, a także o strachu przed protestującymi, wzniesiona przez policję 10 czerwca 2008 r., dwupoziomowa barykada z kontenerów. Fortyfikacja, nazwana fortecą Lee Myung-baka, oddzielała Błękitny Dom ${ }^{62}$ od demonstrantów. Następnego dnia, została usunięta z nakazu Sekretariatu Obrony ${ }^{63}$. Nadto, prezydent, walcząc o swoje przyszłe polityczne życie, musiał wygłosić publiczne przeprosiny, zapowiedział reorganizację gabinetu i renegocjowanie umowy z USA.

Po drugie, ciekawie przedstawia się kwestia importowanego mięsa w kulturowym aspekcie nacjonalizmu i jej wpływ na społeczeństwo. Na przestrzeni lat wraz z rozwojem w sferze gospodarki i demokracji, Korea rozwinęła silną i asertywną tożsamość narodową. Pomimo pokoleniowych różnic dotyczących nastrojów wobec USA, dysydenci stosunkowo łatwo zastosowali nacjonalistyczną ideę oraz zorganizowali masowe demonstracje przeciwko amerykańskim imperialistycznym naruszeniom narodowej, czyt. koreańskiej suwerenności.

Po trzecie, zwyczaj spożywania wołowiny stanowi raczej kulinarną praktykę, podszytą bogactwem kulturowych powiązań. Ponadto,

\footnotetext{
62 Siedziba prezydenta Republiki Korei. Obiekt położony jest w stolicy kraju, Seulu. Nazwa pochodzi od niebieskozielonego koloru dachu głównej części budynku.

${ }^{63}$ South Korean Government Place Containers to Fend off Protesters, „China View” $\mathrm{z}$ dn. 10.06.2008, http://news.xinhuanet.com/english/2008-06/10/content_ 8342297. htm [dostęp: 24-05-2016].
} 
Dominik Wróblewski - Wyzwania konserwatywnej polityki...

mięso jest podstawą koreańskiej kuchni, tworzy emocjonalny, duchowy i psychiczny stosunek z nawykami żywieniowymi Koreańczyków.

Kończąc, polityka dotycząca samej wołowiny w Korei zasługuje na szerszą uwagę, w przeciwieństwie do namacalnej sfery kulturowej. Podejmując kontrowersyjną decyzję, Lee Myung-bak i jego gabinet, starał się zagwarantować dyplomatyczne cele. Niemniej jednak, na skutek kulturowych aspektów nacjonalizmu i pożywienia poniósł polityczne konsekwencje inne od oczekiwanych.

\section{Bibliografia:}

Chae Hae-sook, Kim S., Conservatives and Progressives in South Korea, „Washington Quarterly” 2008, nr 4, s. 77-95.

Chae Su-hong, The Candlelight Protest and the Politics of the Baby Stroller Brigades, „Korea Journal” 2010, nr 3, s. 71-99.

Choe Sang-hun, An Anger in Korea over More Than Beef, New York Times, z dn. 12.06.2008, http://www.nytimes.com/2008/06/12/world/asia/12 seoul.html?_r=0 [dostęp: 24-05-2016].

Cho Hee-yeon, Surendra L., Cho Hyo-je (red.), Contemporary South Korean Society. A Critical Perspective, Routledge Advances in Korean Studies, Routledge, London 2013.

Cho Hong-sik., Globalization and National Identity: Shintobul-i, a Case of Cultural Representation of Economic Nationalism, „Journal of International and Area Studies" 2008, nr 1, 17-35.

'촛불집회' 2년...상처 치유 안된 사회 ['Candlelight Rally' Two Years... A Woundless Society], „Naver” z dn. 12.05.2010, http://news.naver.com/ main/read.nhn?mode=LSD\&mid=sec\&sid1=102\&oid=001\&aid=0003272 745 [dostęp: 24-05-2016].

Consumers Shun Made-in-China Food Products, „Korea Times” z dn. 29.09. 2008, http://www.koreatimes.co.kr/www/news/nation/2008/09/117_ 31847.html [dostęp: 24-05-2016].

Dziak W. J., Strnad G., Republika Korei. Zarys ewolucji systemu politycznego, Instytut Studiów Politycznych PAN, Collegium Civitas, Warszawa 2011.

Farmers in Massive Protests against FTA with U.S., „Chosun Ilbo” z dn. 23.05. 2008, http://english.chosun.com/site/data/html_dir/2008/05/23/2008 052361022.html [dostęp: 24-05-2016]. 
Feffer J., [Elect] A Green Bulldozer?, „Korea Times” z dn. 8.01,2008, http://www.koreatimes.co.kr/www/news/nation/2008/01/116_16889. html [dostęp: 24-05-2016].

"거짓말 대통령, 초반에 버릇 잡아야" 중 - 고등학생이 대거 참가한 촛불집회... 2만여 명 운집 ["Liar President Have to Spoil Early". Candlelight Rallies Attended by many Middle and High School Students...More than 20,000 People], „Pressian” z dn. 4.05.2008, http://www.pressian.com/news/ article.html?no=88527 [dostęp: 24-05-2016].

광우병 괴담 깨졌지만... 시위꾼들, 이슈 바꾸며 '反정부 집회' [The Mad Cow

Disease Ghost Has Broken...Protesters and Anti-Government Rally], "Chosun Ilbo" z dn. 2.05.2008, http://news.chosun.com/site/data/html_ dir/2013/05/02/2013050200038.html?Dep0=twitter\&d=20130502000 38 [dostęp: 24-05-2016].

한국인 광우병 걸릴 확률 높다...PD수첩 '광우병 보도'는 허위 [Koreans are more Likely to Take Mad Cow Disease...PD Note 'Mad Cow Disease Report' is False], „Hankyung” z dn. 2.09.2008, http://news.donga.com/ 3/all/20110906/40105087/1 [dostęp: 24-05-2016].

Ho Ming-sho, Hong Chen-shuo, Challenging New Conservative Regimes in South Korea and Taiwan. Comparison of the Anti-American Beef Protests, „Asian Survey” 2012, nr 4, s. 643-665.

Inside U.S. Trade, Korean Minister Sees Open Beef Market in Two Steps, Delay in FTA Approval, 2007.

Internet $w$ południowej Korei, „Blox” z dn. 07.02.2011, http://internetum. blox.pl/2011/02/Internet-w-poludniowej-Korei.html [dostęp: 24-052016].

Jung Heon-joo, The Rise and Fall of Anti-American Sentiment in South Korea: Deconstructing Hegemonic Ideas and Threat Perception, „Asian Survey” 2010, nr 5, s. 946-964.

Kang Man-gil, Contemporary Nationalist Movements and the Minjung, [w:] Wells K. M. (red.), South Korea's Minjung Movement: The Culture and Politics of Dissidence, University of Hawaii Press, Honolulu, Hawaii 1995.

Kim Eui-young, The Limits of NGO-Government Relations in South Korea, „Asian Survey” 2009, nr 5, s. 873-894.

Kim Jin-wung, Ambivalent Allies: Recent South Korean Perceptions of the United States Forces Korea (USFK), „Asian Affairs” 2004, nr 4, s. 268-285. 
Dominik Wróblewski - Wyzwania konserwatywnej polityki...

Kim Sun-hyuk, Democratization and Social Movements in South Korea: A Civil Society Perspective, [w:] Broadbent J., Brockman V. (red.), East Asian Social Movements: Power, Protest, and Change in a Dynamic Region, Springer, New York 2011.

Kim Seung-hwan, Anti-Americanism in Korea, „Washington Quarterly” 2002, nr 1, s. 109-122.

United States Forces Korea, http://www.usfk.mil/ [dostęp: 24-05-2016].

Kim Yong-cheol, Kim June-woo., South Korean Democracy in the Digital Age: The Candlelight Protests and the Internet, „Korea Observer” 2009, nr 1, s. 53-83.

Koo Hagen, The State, Minjung, and the Working Class in South Korea, [w:] Koo Hagen (red.), State and Society in Contemporary Korea, Cornell University Press, New York 1993.

Korea JoongAng Daily, http://koreajoongangdaily.joins.com/news/article/ Article.aspx?aid=2895391 [dostęp: 24-05-2016].

Korea Meat Trade Association, Consumption, http://www.kmta.or.kr/eng/ sub4-1.html?scode=6\&kej=eng [dostęp: 24-05-2016].

Lee Sook-jong, Democratization and Polarization in Korean Society, „Asian Perspective" 2005, nr 3, s. 99-125.

Lee Ho-yeon, Park Tae-yong, Civil Participation in the Making of a New Regulatory State in Korea: 1998-2008, „Korea Observer” 2009, nr 3, s. 461493.

Lee's Campaign Pledges Need Another Look, „Chosun Ilbo” z dn. 24.12.2007, http://english.chosun.com/site/data/html_dir/2007/12/24/200712246 1020.html [dostęp: 24-05-2016].

Mahoney J., Path Dependence in Historical Sociology, „Theory and Society” 2000, nr 4, s. 507-548.

$\mathrm{MBC}$ “광우병 보도 국민에 사과” [MBC "Apology to the Mad Cow News People"], „DongA” z dn. 9.09.2008, http://news.donga.com/3/all/201109 06/40105087/1 [dostęp: 24-05-2016].

McAdam D., Conceptual Origins, Current Problems, Future Directions [w:] McAdam D., McCarthy J. D., Zald M. Y. (red.), Comparative Perspectives on Social Movements. Political Opportunities, Mobilizing Structures and Cultural Framings, Cambridge Studies in Comparative Politics, Cambridge 1999. 
'미친 소 못먹어', 청계광장 물들인 촛불2만여명 운집... 곳곳서 즉석 '자유발언' ['I Cannot Eat Crazy Cow', a Candle in Cheonggye Plaza. 20,000

People Gathered in Cheonggye Plaza], „Ohmy News” z dn. 24.05.2008, http://www.ohmynews.com/NWS_Web/View/at_pg.aspx?CNTN_CD $=$ A0 000892031\&PAGE_CD=N0000\&BLCK_NO=3\&CMPT_CD $=$ M0001\&NEW_G $\mathrm{B}=$ [dostęp: 24-05-2016].

Min Kyung-bae, Analog Government, Digital Citizens, „Global Asia” 2008, nr 3 , s. 94-103.

[美쇠고기 고시 이후] 이회창 “집단폭력 가한 사람은 폭도” [After the Beef

Notification], „Seoul Newspaper” z dn. 28.06.2008, http://www.seoul.co. kr/news/newsView.php?id=20080628004009 [dostęp: 24-05-2016].

Mitchell D. J. (red.), Strategy and Sentiment: South Korean Views of the United States and the U.S.-ROK Alliance, Center for Strategic and International Studies, Washington 2004.

Moon Chung-in., South Korea in 2008: From Crisis to Crisis, „Asian Survey” 2009, nr 1, s. 120-128.

무이코 조사관 “촛불집회 주도자 없이 스스로 참여” [Muiko Inspector "Participate in Candlelight Vigils without a Leader"], „Khan Newspaper” $\mathrm{z}$ dn. 18.07.2008, http://news.khan.co.kr/kh_news/khan_art_view html? artid=200807181833465\&code=940100 [dostęp: 24-05-2016].

Office of the US Trade Representative, https://ustr.gov/trade-agreements/ trade-investment-framework-agreements [dostęp: 24-05-2016].

Oh Chang-hun, Arrington C., Democratization and Changing Anti-American Sentiments in South Korea, „Asian Survey” 2007, nr 2, s. 327-350.

People's Solidarity for Participatory Democracy, http://www.peoplepower 21.org/English [dostęp: 24-05-2016].

Pew Research Center, Obama More Popular Abroad Than at Home, Global Image of U.S. Continues to Benefit: 22-Nation Pew Global Attitudes Survey.

Rastegari Henneberry S., Hwang Seong-huyk, Meat Demand in South Korea: An Application of the Restricted Source-Differentiated Almost Ideal Demand System Model, „Journal of Agricultural and Applied Economics” 2007, nr 1, s. 47-60.

[사설]'폭도가 된 시위꾼들'에게 언제까지 짓밟힐 텐가 [How Long Are You Going to Be Trampled on by 'Mobsters Who Are Mobs'?], „DongA” z dn. 
Dominik Wróblewski - Wyzwania konserwatywnej polityki...

27.06.2008, http://news.donga.com/3/all/20080627/8595712/1 [dostęp: 24-05-2016].

Snow D. A., Benford R. D., Ideology, Frame Resonance, and Participant Mobilization. [w:] Klandermans B., Kriesi H., Tarrow S. (red.), From Structure to Action: Comparing Social Movement Research across Cultures, Greenwich, London 1988.

'쇠고기 시위' 참석 고교생에 가산점 [Beef Demonstration, High School Student Point], „DongA” z dn. 21.11.2008, http://news.donga.com/3/all/ 20081121/8660831/1 [dostęp: 24-05-2016].

South Korean Government Place Containers to Fend off Protesters, „China View” z dn. 10.06.2008, http://news.xinhuanet.com/english/2008-06/ 10/content_8342297.htm [dostęp: 24-05-2016].

South Korean President Impeached, „BBC” z dn. 12.03.2004, http://news.bbc. co.uk/2/hi/asia-pacific/3504026.stm [dostęp: 24-05-2016].

South Korea's Ministry of Culture, Sport and Tourism, http://www.mct.go. $\mathrm{kr} / \mathrm{html} /$ symbolImg/eng/bulgogi/sec01.html [dostęp: 24-05-2016].

South Korea's Ministry of Foreign Affairs, http://www.mofa.go.kr/ENG/ policy/fta/status/overview/index.jsp?menu=m_20_80_10\&tabmenu=t_1 [dostęp: 24-05-2016].

Strnad G., Korea. Polityka południa wobec Północy w latach 1948-2008. Zmiana i kontynuacja, Instytut Zachodni, Poznań 2014.

Strnad G., Południowokoreańska droga do demokracji, Wydawnictwo Adam Marszałek, Toruń 2010.

Toxic Substance Found in Chinese-Made Korean Snacks, „Chosun Ilbo” z dn. 25.09.2008,

http://english.chosun.com/site/data/html_dir/2008/09/25/200809256 1011.html [dostęp: 24-05-2016].

Yankees Go Home, http://www.soulinseoul.pl/2015/08/02/yankees-gohome/ [dostęp: 24-05-2016]. 